\title{
Independent evolution of matrotrophy in the major classes of Bryozoa: transitions among reproductive patterns and their ecological background
}

\author{
Andrew N. Ostrovsky ${ }^{1,4, *}$, Dennis P. Gordon ${ }^{2}$, Scott Lidgard ${ }^{3}$ \\ ${ }^{1}$ Department of Invertebrate Zoology, Faculty of Biology \& Soil Science, St. Petersburg State University, \\ Universitetskaja nab. 7/9, 199034, St. Petersburg, Russia \\ ${ }^{2}$ National Institute of Water \& Atmospheric Research, Private Bag 14901, Kilbirnie, Wellington, New Zealand \\ ${ }^{3}$ Department of Geology, Field Museum of Natural History, 1400 S. Lake Shore Dr., Chicago, Illinois 60605, USA \\ ${ }^{4}$ Present address: Department of Palaeontology, Faculty of Earth Sciences, Geography and Astronomy, Geozentrum, \\ University of Vienna, Althanstrasse 14, 1090 Vienna, Austria
}

\begin{abstract}
Bryozoa are unique among invertebrates in possessing placenta-like analogues and exhibiting extraembryonic nutrition in all high-level (class) taxa. Extant representatives of the classes Stenolaemata and Phylactolaemata are evidently all placental. Within the Gymnolaemata, placentalike systems have been known since the 1910s in a few species, but are herein reported to be widespread within this class. Placental forms include both viviparous species, in which embryonic development occurs within the maternal body cavity, and brooding species, in which development proceeds outside the body cavity. We have also identified an unknown reproductive pattern involving macrolecithal oogenesis and placental nutrition from a new, taxonomically extensive anatomical study of 120 species in 92 genera and 48 families of the gymnolaemate order Cheilostomata. Results support the hypothesis of evolution of oogenesis and placentation among Cheilostomata from oligolecithal to macrolecithal oogenesis, followed by brooding, through incipient matrotrophy combining macrolecithal oogenesis and placentation, to oligolecithal oogenesis with subsequent placental brooding. The distribution of reproductive patterns within the phylum suggests that variations of placentation evolved in all 3 bryozoan classes, and possibly several times within both gymnolaemate orders. We infer that extraembryonic nutrition may be advantageous to species through enhanced developmental plasticity, and, in fast-growing ephemeral colonies, simultaneous volumetric growth and embryonic development may facilitate earlier larval release and occupation of vacant space.
\end{abstract}

KEY WORDS: Matrotrophy $\cdot$ Placenta $\cdot$ Reproductive patterns $\cdot$ Evolution $\cdot$ Bryozoa Resale or republication not permitted without written consent of the publisher

\section{INTRODUCTION}

Matrotrophy, or extraembryonic nutrition (EEN), is considered the most complex nutritional relationship between a parent and an embryo, enhancing offspring fitness under certain circumstances (Wourms \& Lombardi 1992, Mousseau \& Fox 1998, Trexler \& DeAngelis 2003, Marshall \& Uller 2007). It occurs in both viviparous and some brooding animals by a variety of methods (oophagy, adelphophagy, histophagy, placental nutrition). The most complex variant is pla- centation, involving intimate contact or even fusion of the fetal and parental tissues and 'nutrient transfer via cell secretions or blood constituents' to the embryo or its enclosing space (Crespi \& Semeniuk 2004, p. 638). The distribution of matrotrophy in the Eumetazoa is strikingly scattered. Basically, a few species in some genera or families within a class or phylum exhibit matrotrophy, whereas the others lack it. For instance, nutrient transfer from the maternal organism to the embryo is known in 1 scyphozoan jellyfish, a few cestode flatworms, a polychaete, several species of gas- 
tropods and of bivalve molluscs, 2 kamptozoans, and 3 echinoderms. Matrotrophy is more common within the Arthropoda, in which EEN is characteristic of 2 families of scorpions, several isopod crustaceans, some genera in a few orders of insects, and 2 genera of mites. It is also found in 2 families of Onychophora, 2 species of Ascidiacea, numerous families of elasmobranch and bony fishes, and in some amphibians and reptiles. Most species in these groups are either oviparous or viviparous, but not matrotrophic (Giese \& Pearse 1974, 1975a,b, 1977, Giese et al. 1979, 1987, 1991, Wourms et al. 1988, Adiyodi \& Adiyodi 1989, 1990, Blackburn 1992, Charmantier \& CharmantierDaures 1994, Schwartz \& Dimock 2001, Crespi \& Semeniuk 2004, Korneva 2005, von Rintelen \& Glaubrecht 2005, Glaubrecht et al. 2006, Koya \& Munoz 2007, Reznick et al. 2007). Exceptions to patchy distribution of EEN are the Pseudoscorpionida, Salpida (Tunicata), and placental mammals, in which it occurs in all species (Weygoldt 1969, Bone 1998, Lombardi 1998, Mess \& Carter 2007).

The phylum Bryozoa, all species of which are colonial suspension feeders, is an exception too, as we report below. All extant species of the class Stenolaemata (order Cyclostomata) are viviparous, possessing specialized nutritive tissue and embryos that are incubated intracoelomically in characteristic brooding zooids (gonozooids) (Harmer 1893, 1896, 1898, Borg 1926). Insofar as these gonozooids are known in fossil cyclostomes (Taylor \& Michalik 1991, Lidgard et al. 1993), matrotrophy is inferred to have existed in this order at least since the Late Triassic. Similarly, all species of the class Phylactolaemata studied so far have EEN by either spot- or ring-like placental analogues, developing inside a brooding sac the cavity of which is external relative to the maternal body cavity (Braem 1890, Brien 1953). In Gymnolaemata, the largest bryozoan class with >1000 genera, matrotrophy was, until recently, known only in relatively few taxa - in the viviparous family Epistomiidae (genera Epistomia, Synnotum) and in the families Bugulidae (Bicellariella, Bugula), Candidae (Scrupocellaria), and Hippothoidae (Celleporella). These taxa are among the majority of gymnolaemates that brood their embryos in extrazooidal incubation chambers (ovicells) (Marcus 1938, 1941, Woollacott \& Zimmer 1972, 1975, Dyrynda 1981, Dyrynda \& King 1982, 1983, Dyrynda \& Ryland 1982, Hughes 1987. Santagata \& Banta 1996, Ostrovsky 1998).

We report here the results of an extensive lightmicroscopic anatomical study, revealing that EEN is far more common in gymnolaemates than previously realized. The results point out seemingly independent appearances of matrotrophy. To the extent that broad similarities - and independent acquisition - evidenced in these cases hold true, they imply that transitions in reproductive patterns have occurred repeatedly among gymnolaemate lineages. We also offer some provisional ecological considerations based on our survey, increasing awareness of the importance of maternal provisioning among marine animals, and recent ecological studies of cheilostome bryozoans.

\section{MATERIALS AND METHODS}

Specimens were collected by various methods and fixed either in $2.5 \%$ glutaraldehyde (buffered in $0.1 \mathrm{M}$ Na-cacodylate with $10.26 \%$ sucrose, $\mathrm{pH} 7.3$ ) or Bouin's fluid without acetic acid. While still in fixative they were decalcified for 6 to $12 \mathrm{~h}$ using a few drops of a $2 \mathrm{~N}$ solution of hydrochloric acid; gradually dehydrated in an ethanol series (40-50-60-70-80-90-96\%), embedded in plastic (epoxy resin type TAAB 812), sectioned $(1.0 \mu \mathrm{m}$ thick) with a glass knife, and stained with Richardson's stain (1\% water solution of methylene blue, Na-tetraborate and azur II, mixed in proportions 1:1:2) using standard methods (Richardson et al. 1960). Sections were observed and digital images were made with Nikon 104 and Nikon 118 FXA dissecting light microscopes.

Altogether, sections of 120 species belonging to 92 genera and 48 families of the gymnolaemate order Cheilostomata were prepared and studied (Table 1). Our criteria for recognizing extraembryonic nutrition include comparing the size of the zygotes/early embryos and late embryos/larvae, and/or comparing the epithelial lining of empty and incubating brood chambers, since EEN is mediated via the hypertrophied epithelial cells (embryophore) that develop inside these chambers (Fig. 1). Simultaneously anatomical study of oogenesis was undertaken aiming to recognize the type and numbers of oocytes.

\section{RESULTS}

\section{Anatomical data}

In addition to the above-mentioned taxa, we found EEN in the families Flustridae (genera Gregarinidra, Isosecuriflustra, Klugeflustra), Beaniidae (Beania), Cellariidae (Cellaria), Microporidae (Micropora), Cribrilinidae (Figularia), Catenicellidae (Costaticella, Cribricellina, Pterocella), Watersiporidae (Watersipora), Lanceoporidae (Calyptotheca), Myriaporidae (Myriapora), and Urceoliporidae (Reciprocus, Urceolipora).

Placental analogues are represented structurally by hypertrophied epithelial cells (embryophore) of the maternal body wall transporting nutrients to the brooding cavity by exocytosis in Cheilostomata. In its 

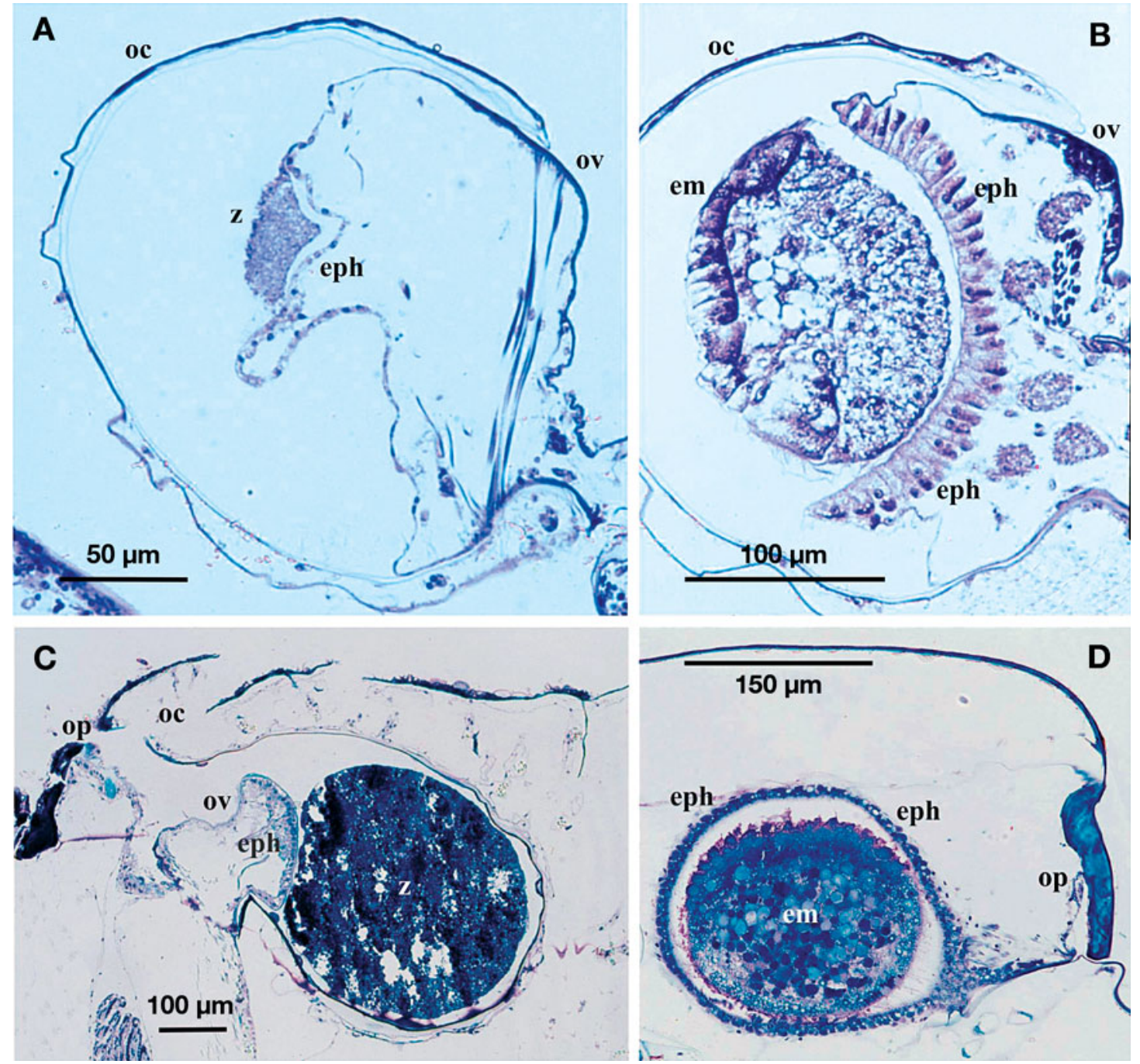

Fig. 1. Longitudinal sections through brood chambers with placental analogues in 3 cheilostome bryozoans (light microscopy). (A,B) Bugula flabellata (Bugulidae) (Pattern III): (A) ovicell with an oligolecithal zygote and non-developed embryophore and (B) partly grown embryo and fully developed embryophore. (C) Ovicell of Myriapora truncata (Myriozoidae) with an embryophore and macrolecithal zygote (Pattern IV). (D) Internal brood sac of Reciprocus regalis (Urceoliporidae) with partly grown embryo (Pattern III). em: embryo; eph: embryophore; oc: protective fold of the ovicell; op: zooidal operculum; ov: ooecial vesicle; z: zygote

turn, the embryo consumes them from a surrounding liquid by endocytosis (Woollacott \& Zimmer 1975, Hughes 1987). The embryo is either freely suspended within a brooding cavity, or in contact with an embryophore. Normally (but not always), a zygote/young embryo is suspended and does not touch the wall of the brood chamber. During its growth it gradually occupies most or all of the brooding cavity and nestles close to the embryophore.

Placental analogues occur within both ovicells (Fig. 1A-C) and internal brooding sacs (Fig. 1D). Maximal recorded increase in embryo volume during development was 257.7-fold (Reciprocus regalis); minimal increases were 1.27- and 1.49-fold (Isosecuriflustra angusta and Figularia figularis, respectively). Increases reported in the literature range from 2.1(Scrupocellaria ferox) to 500-fold (Bugula neritina) and even 1000-fold (Epistomia bursaria) (Santagata \& Banta 1996, Woollacott \& Zimmer 1972, Dyrynda \& King 1982).

Based on the type of oogenesis and presence or absence of extraembryonic nutrition, 4 reproductive patterns were recognized (Table 1). The least common is the oviparous pattern (Pattern I) accompanied by a production of many small oligolecithal oocytes (little or no yolk), whereas the most common pattern involves consecutive embryonic incubation of a few large macrolecithal oocytes (relatively large yolk) without 


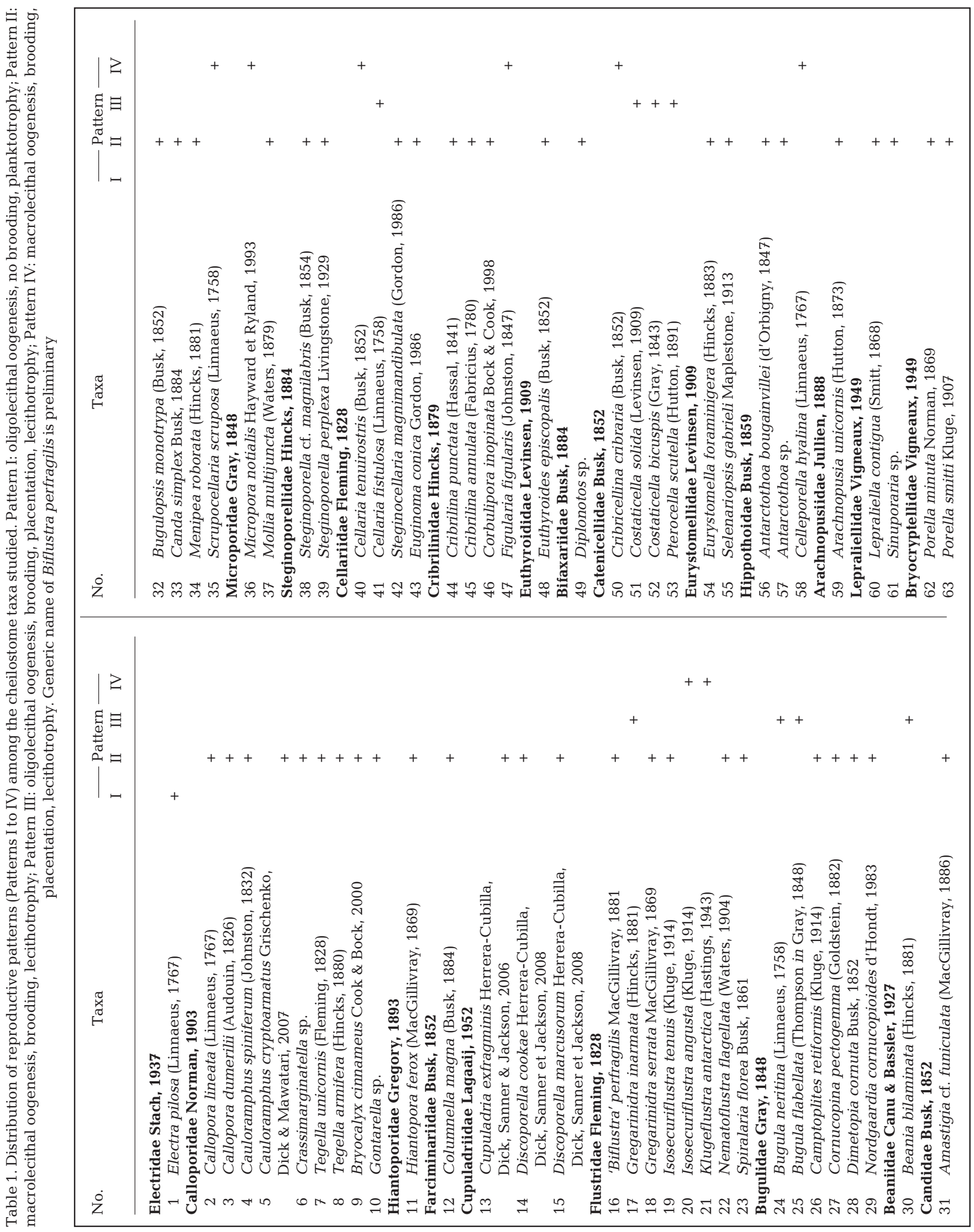




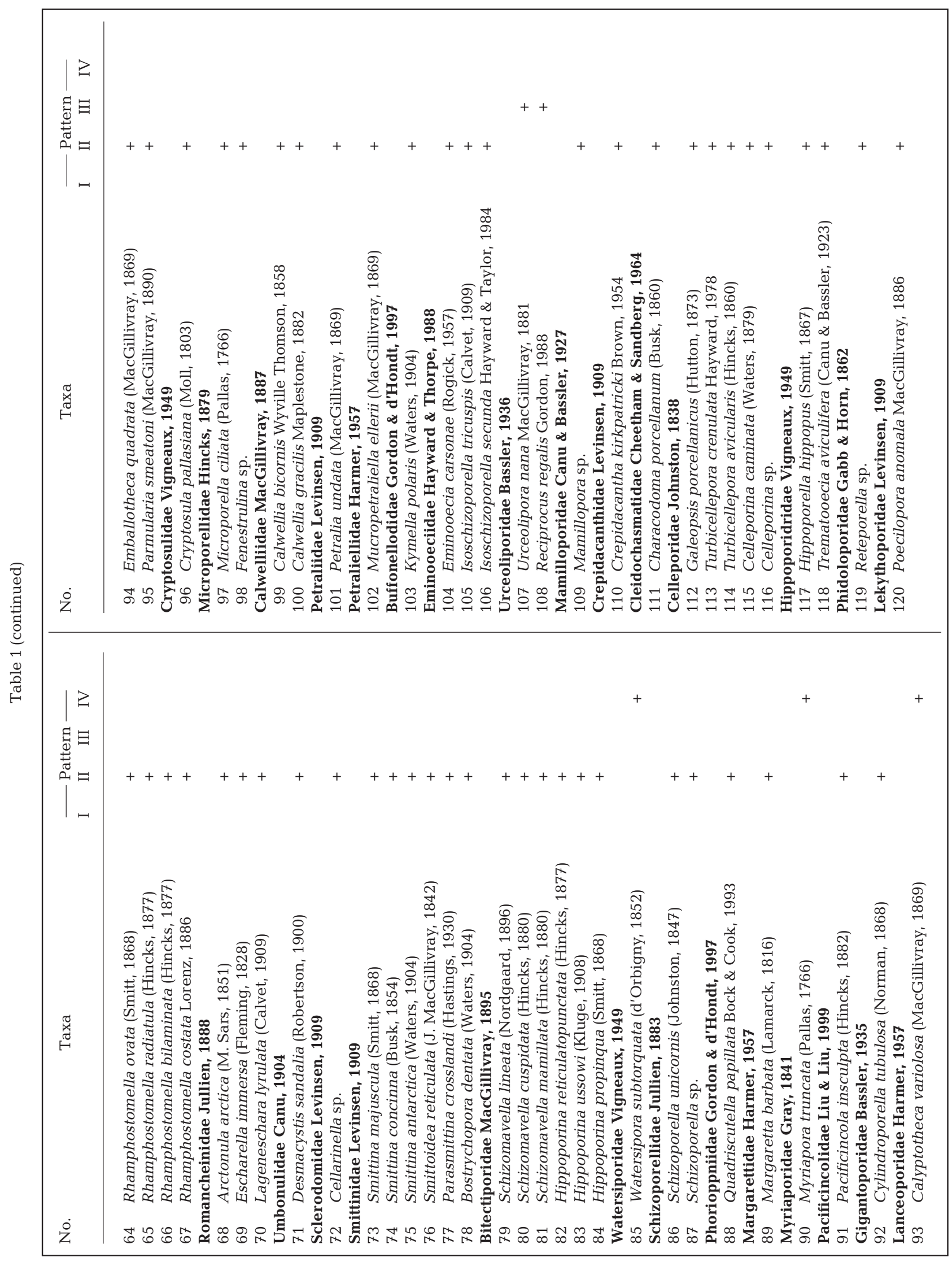


EEN in the brood chamber (Pattern II). Two other reproductive patterns involve both brooding and matrotrophy, with production of either a few small oligolecithal (Pattern III) or a few large macrolecithal oocytes (Pattern IV). Patterns I to III have previously been described (and enumerated) in the literature (Harmer 1926, Woollacott \& Zimmer 1975, Reed 1991), whereas Pattern IV is recorded here for the first time.

Different patterns involving brooding and EEN were sometimes met within one and the same family and even the same genus. Patterns II and IV occur in Isosecuriflustra, Celleporella Candidae, Microporidae, Cribrilinidae, and Hippothoidae; Patterns II and III in Gregarinidra and Bugulidae; Patterns III and IV in Cellaria and Catenicellidae (also, possibly, Pattern II in the latter family, see Marcus 1938); and Patterns II, III, and IV in Flustridae and Cellariidae.

\section{Data from the literature}

Reanalysis of bryozoan taxonomic literature also shows that matrotrophy has been described several times in cheilostomes by earlier scholars, but these findings were either not understood or were overlooked. Based on published descriptions and illustrations, EEN also exists in Retiflustra (Flustridae), Poricellaria (Poricellariidae), Catenicella (Catenicellidae), Adeona and Adeonellopsis (Adeonidae), Adeonella, Laminopora (Adeonellidae), and Hippopodina (Hippopodinidae) (Harmer 1902, 1926, Waters 1912, 1913, Marcus 1938; summarized in Ostrovsky 2008, Ostrovsky et al. 2008). Thus, 18 families and 29 cheilostome genera are now known to exhibit EEN. There is also evidence that it exists in Crassimarginatella falcata (Calloporidae) (Cook 1985). So far, all examined species of Bugula, Cellaria, Catenicellidae, Adeonidae, Adeonellidae, and Urceoliporidae have placental analogues.

A substantial increase in embryo size has been reported in 8 brooding species of the gymnolaemate order Ctenostomata - in the families Flustrellidridae (Flustrellidra), Sundanellidae (Sundanella), Nolellidae (Nolella), Walkeriidae (Walkeria), Mimosellidae (Mimosella), and Vesiculariidae (Zoobotryon) (Joliet 1877, Prouho 1892, Pace 1906, Waters 1914, Braem 1939, Silén 1942, 1944, Banta 1968). This suggests they possess EEN. The structure of the 'ectodermic cushion' described in the embryo sac of the 'protoctenostome' Labiostomella gisleni (see Silén 1944) also suggests that it could be a placental analogue. The above-mentioned family-level taxa (those examined in our and previous studies and those inferred from the literature) are representative of almost half of the gymnolaemate superfamilies with extant species. Such a wide distribution within the phylum thus makes Bryozoa unique among invertebrates. At our present state of understanding, matrotrophy in Bryozoa can be regarded as ubiquitous in 2 living classes (Stenolaemata and Phylactolaemata) and broadly distributed in the Gymnolaemata.

\section{DISCUSSION}

\section{Origin of bryozoan placental analogues}

The question arises as to the origin of bryozoan placental analogues. The phylum Bryozoa lacks a wellresolved, robust phylogenetic framework. Relationships among both traditional higher level taxa, and lower level instances of various reproductive patterns, are inevitably subject to validation as this framework is developed, which is beyond the scope of the present paper. Our discussion thus relies on: current understanding of inter-group relationships; concordance or discordance among higher taxonomic groups, many of which are putatively monophyletic; diverse skeletal morphological characters (many 'non-reproductive' in nature) that presently differentiate these groups; temporal sequences in the fossil record; and comparative patterns of sexual reproduction.

Bryozoans are simultaneous hermaphrodites with spermcast mating (Bishop \& Pemberton 2006). Aquatic spermatozoa are released and subsequently captured to inseminate retained eggs within or near an ovary. In oviparous species, many small oligolecithal oocytes are produced simultaneously and spawned freely into the seawater, each developing into a long-lived planktotrophic larva (cyphonautes). This oviparous pattern of reproduction (Pattern I) is restricted to relatively few gymnolaemates, both ctenostomes and cheilostomes. A second pattern (II) is the most common, in which a few large macrolecithal oocytes are produced sequentially and develop within the vestibulum or lophophoral tentacle sheath or in specialized brood chambers. Most gymnolaemates appear to follow this pattern. In the third pattern (III), a few small oligolecithal oocytes are produced sequentially and receive extraembryonic nutrition during embryogenesis in specialized brood chambers. This pattern is characteristic of some gymnolaemates (Fig. 1A,B,D). Patterns II and III both result in short-lived lecithotrophic (coronate) larvae. Cheilostomata exhibit all 3 patterns (Harmer 1926, Woollacott \& Zimmer 1975, Reed 1991), facilitating comparisons that can inform us about the relative likelihoods of different evolutionary scenarios.

Oviparity, characteristic of the earliest and lessderived malacostegan cheilostomes, is conventionally considered to be the ancestral pattern (e.g. Todd 2000). Basic differences between this and Pattern II are the types of oogenesis and broadcasting versus brooding. 
The origin of Pattern II is obviously based on a shift in oogenesis towards the production of a few large macrolecithal oocytes instead of many small oligolecithal ones. This shift would eventually result in the evolution of the non-feeding coronate larva that is characteristic of most cheilostomes, considered to be a trigger for cheilostome diversification (Taylor 1988). Also, this development is inferred to have been correlated with the origin of extrazooidal incubation of embryos in brood chambers, since all known bryozoan species with non-feeding larvae are brooders. We suggest that the evolution of extrazooidal brooding may be correlated with greater embryonic survival, offsetting a decrease in fecundity following the described shift in oogenesis (cf. Strathmann 1985, 2007).

Although cheilostome bryozoans with reproductive Patterns I and III share a common character - oligolecithal oocytes - it is unlikely that the third pattern would originate from the first. All cheilostome families and genera with extant representatives having placental analogues are well-nested within higher level groups whose other constituent taxa have reproductive Pattern II, which is the most common. Families and genera with living placental species also appear later in the fossil record than their non-placental brooding relatives. The earliest ovicell-like brood chambers in the cheilostome fossil record evolved from external spines, and are thought to have given rise to other lineages with more complete ovicell morphotypes, yet the earliest forms lack any overt indication of placental nutrition (Ostrovsky \& Taylor 2005). Thus, we hypothesize that reproductive Pattern III appeared last in cheilostome evolution; the placenta evolved first, followed by a shift in oogenesis from macrolecithal to oligolecithal. In testing this hypothesis through our survey, we expected to find a pattern combining the characteristics of Patterns II and III, i.e. species with a few macrolecithal oocytes consecutively developing in the ovary and later receiving EEN at the brooding site via a placental analogue during embryogenesis.

Detailed anatomical study of oogenesis supports our hypothesis. We found a new pattern (Pattern IV) in 11 genera of 10 cheilostome families, combining macrolecithal oogenesis and placentation, which can be considered incipient matrotrophy (Fig. 1C, Table 1). In general, species having Pattern IV have a lessdeveloped embryophore and an embryonic increase in volume smaller than in species with Pattern III, which are mainly dependent on EEN. We can thus infer that, whereas brooders ancestrally had large yolky oocytes, no placenta and EEN (Pattern II), they later acquired a placenta and EEN without any change in the type of female gametic production (Pattern IV). The next step was likely a precocious oviposition of submature oocytes, because part of the nutrients can be moved to it via the placental analogue (embryophore) in a brooding site. Progressively earlier oviposition required more placental activity, and finally embryophores began to play a major role in providing nutrition to the progeny. Placental cells became larger and more active, whereas the female gonad gradually changed to production of smaller oocytes (Pattern III). Altogether, these events resulted in a shift in oogenesis, since the ovary restricted its activity to the early stages of oocytic growth. We infer that nutrient distribution to the oocytes in the ovary became supplemented by, or dominated by, distribution to the embryos in the brood chamber. A similar shift from large to small (but macrolecithal) oocytes during a transition to the intraovarian incubation accompanied by cannibalism, has been hypothesized for some viviparous sea stars (Byrne 1991, 1996, Byrne \& Cerra 1996). In this case, such a shift might be connected with a transition to the early onset of cleavage occurring within a gonad.

The occurrence of matrotrophy cannot be established definitively from cheilostome fossils, but what is presently known of cheilostome phylogeny (Gordon 2000) supports the above hypothesis. Also, the existence of different reproductive patterns, which are 'adjacent' to one another in a hypothetical series, within the same families and sometimes the same genera underlies the sequence of evolutionary transitions that we have suggested above, exemplified by Isosecuriflustra, Celleporella, Candidae, Microporidae, Cribrilinidae, and Hippothoidae (Patterns II and IV), Cellaria and Catenicellidae (Patterns III and IV), and Flustridae and Cellariidae (Patterns II, III, and IV). This taxonomic distribution strongly supports the idea that such transitions were not intractable evolutionarily and that EEN and placental analogues evolved multiple times within the Cheilostomata.

Viviparity in cheilostomes, known in the family Epistomiidae, could be considered as an additional, fifth reproductive pattern that evolved from Pattern II or III when embryos began to develop directly in the ovary and received EEN. External brood chambers likely disappeared in this lineage. An analogous pattern occurs in the Cyclostomata, although it almost certainly evolved independently (see below).

The taxonomic pattern of the distribution of matrotrophy within the phylum strongly supports the idea of its independent evolution in all 3 bryozoan classes and possibly several times within both gymnolaemate orders, reminiscent of the situation within vertebrates, in which EEN evolved independently numerous times in different lineages of fishes, amphibians, and reptiles (Blackburn 1992, Wourms \& Lombardi 1992, Lombardi 1998, Trexler \& DeAngelis 2003, Crespi \& Semeniuk 2004).

Suggesting independent origins of placentation within the major bryozoan classes and orders of the 
phylum, we specifically considered conventional views of major group relationships, distribution of the reproductive patterns (planktotrophy versus lecithotrophy), and differences in the origin of brood chambers. Considering the Ctenostomata (Gymnolaemata) to be a paraphyletic stem group for the Stenolaemata and Cheilostomata (Gymnolaemata) (Todd 2000), and recognizing planktotrophy in at least 3 ctenostome superfamilies, we suggest that the first cheilostomes also possessed a planktotrophic larva. Further, brooding and lecithotrophy evolved in cheilostomes, and the presence of 2 and sometimes 3 reproductive patterns ( 1 or 2 of which are placental) within the same families and even genera supports the idea that placentation evolved numerous times within this order. Increase in embryo size during brooding has been recorded in 4 ctenostome superfamilies. In 2 of them, planktotrophy also has been recorded. Thus, a conservative inference is that ctenostomes acquired placentation at least twice.

Cyclostomata (Stenolaemata) are viviparous. There are no viviparous ctenostomes known as yet. Placental ctenostomes brood their embryos outside the body cavity, either within brooding sacs (body wall invaginations) or within the introvert. Their placental organs are derivatives of the zooidal body wall. In contrast, placental organs in cyclostomes are derivatives of the ovary and coelothelium. Even if the ctenostome ancestor of Cyclostomata was a brooder, placentation in the ovary should evolve anew in this order.

The most problematic case is presented by the Phylactolaemata, whose precise relationships with the rest of the Bryozoa remain very obscure. Stark differences in morphology suggest their very early origin, probably from a ctenostome ancestor. Phylactolaemata are all placental, brooding their embryos inside brood sacs (body wall invaginations) similar to some placental ctenostomes from the superfamily Victorelloidea and in Labiostomella ('Protoctenostomata') (Ström 1977, Silén 1944, Todd 2000). Victorelloidea are thought to be among the youngest ctenostome superfamilies, not closely allied with Labiostomella. Overall sexual reproductive patterns of Labiostomella and Phylactolaemata are similar, but Phylactolaemata possess a ring- or spot-like placental structure, quite unlike the hypertrophied epithelial lining that exists in the placental victorelloids and 'ectodermic cushion' recorded in Labiostomella. Modes of oviposition are also different in the phylactolaemates and ctenostomes.

\section{Ecological and evolutionary considerations of matrotrophy in cheilostome Bryozoa}

Matrotrophy can be considered a maternal or parental effect, a form of phenotypic plasticity that spans gener- ations (Uller 2008). Effects such as matrotrophy (and the plasticity they express) may carry proximate selective advantages in generational or ecological time, under certain circumstances. These circumstances could include: temporal or spatial fluctuations in the environment; conditions for offspring that are predictable from the parental conditions; low costs of interaction and transmission for both parents and offspring; and low levels of parent-offspring conflict, such that different optimal plasticity levels for parents and offspring do not reduce the fitness in either. Yet parental effects are not uniformly adaptive. They involve trade-offs (Trexler \& DeAngelis 2003), and the costs and benefits are mediated by the respective strengths of selection on parents versus offspring, depending upon ecological contexts (Marshall \& Uller 2007, Marshall et al. 2008a, Uller 2008).

In evolutionary time, differential allocation patterns to oocytes and to embryos are explicit among the reproductive patterns recognized in bryozoans, and both proximate and ultimate factors are in play (Wourms \& Lombardi 1992, Uller 2008). Even within certain of these reproductive patterns, flexibility in parental investment in offspring (Marshall \& Keough 2008a,b, Marshall et al. 2008b) is likely greater than in others. In particular, the degree of matrotrophy can be quite variable. Parent-offspring conflict influencing these transitions is also likely: How are parent and offspring fitness conditions that have been established under one reproductive pattern influenced in such a way as to make possible novel evolution of another pattern? We may conjecture, on the basis of multiple putative transitions in the direction of matrotrophy in bryozoans, that both natural selection and 'developmental bias' (Arthur 2004) may have played roles in (possibly convergent) acquisition and retention of novel reproductive patterns. Accepting that the implications of transitions in reproductive patterns and of parental investment are not yet clear (Reznick et al. 2007, Uller 2008), we offer some preliminary considerations about their existence in cheilostome bryozoans.

Bryozoan matrotrophy, variable maternal provisioning, and offspring size are all probably related interactively to areal and temporal environmental variation at several scales (Marshall \& Keough 2008a,b, Marshall et al. 2008a,b). In the simplest form, an increase in the maternal provisioning to gamete or embryo may lead to larger, fitter offspring, but potentially at the cost of lowered fecundity because of the higher energy and space investment per offspring. Pattern I species with oligolecithal oogenesis and no brooding produce planktotrophic larvae, the reproductive strategy with the least developmental plasticity and the least maternal investment. To the extent that they persist in the plankton much longer than nonfeeding larvae, they 
are more likely to encounter habitats different from and less predictable than that of the parents. However, this persistence may also enable them to maintain selectivity among habitats for longer periods of time (Elkin \& Marshall 2007). Provisioning of lecithotrophic larvae, by contrast, provides a greater scope of size variation and often a means of buffering the next generation against stresses in the environment, increasing offspring fitness. For example, Marshall \& Keough (2003) showed that in the cheilostome genera Bugula and Watersipora, both with variable sizes of lecithotrophic larvae, larger larvae could delay metamorphosis in the absence of settlement cues. Larger larvae of $B$. neritina also grow more quickly, survive better, reproduce sooner and more abundantly, and produce colonies in the next generation with larger larvae than do smaller initial larvae (Marshall et al. 2003). Similar size effects were found by Marshall \& Keough (2004) for $W$. subtorquata. However, the size effects are not uniform, as subsequent experiments with $B$. neritina showed that larval duration interacts with size to produce complex effects after metamorphosis (Marshall \& Keough 2006). Different intensities of post-metamorphic competition in $B$. neritina, conditioned according to the density of colonies, were used by Allen et al. (2008) to show that large offspring size is not always optimal; mothers produced smaller larvae at low colony densities. Producing larvae too large for a given time and habitat presumably has a cost in lost fecundity. This suggests that within-species plasticity in maternal provisioning can act to maximize both maternal and offspring fitness. Plasticity in bryozoan maternal provisioning and offspring size may also be adaptive at inter-population scales and with changing seasonal conditions (Marshall \& Keough 2008b, Marshall et al. 2008a). Interestingly, both B. neritina and W. subtorquata are placental species, with reproductive Patterns III and IV, respectively (Table 1).

Matrotrophy may be favored where offspring conditions are predictable from parental conditions, or where environmental fluctuations occur. Lecithotrophic bryozoan larvae have limited dispersal, and some are philopatric or settle gregariously near conspecifics (Jackson 1986), ensuring predictable environments across generations. In fluctuating or unpredictable environments, flexibility in matrotrophy may facilitate 'bet-hedging' strategies, enabling mothers to produce a range of offspring sizes, potentially maximizing reproductive success across narrow, changing fitness optima; this strategy appears to hold for Bugula neritina and may be common (Marshall et al. 2008b). Sperm storage may be widespread in lecithotrophic gymnolaemates (Bishop \& Pemberton 2006), and may increase developmental plasticity in concert with matrotrophy, possibly in response to varying environmen- tal conditions. Celleporella hyalina with reproductive Pattern IV can adjust matrotrophic allocations based on receipt of sperm (Bishop et al. 2000, Hughes et al. 2002). Together with sperm storage, this would possibly give greater flexibility in response to adverse or fluctuating environmental conditions. Egg-sperm fusion occurs at or near the time of ovulation in oviparous gymnolaemates, whereas it is very early (precocious) and intraovarian in all brooding cheilostomes studied, including placental ones. Insemination by stored sperm can trigger normal oogenesis, which results in oviposition and the beginning of EEN in placental species. If mothers have some control over the induction of vitellogenesis and over allocation and larval provisioning in response to environmental cues, developmental plasticity is increased with regards to any of these processes acting alone.

The transition from lecithotrophic brooding without matrotrophy to matrotrophy via a placental analogue is a dramatic shift in the timing of resource allocation: from a major investment in offspring yolk resource before a fusion of male and female pronuclei in an inseminated oocyte to an investment after such fusion and through gestation (irrespective of prior yolk development in the oocyte in the second case). With this shift, parentoffspring interaction is accentuated, as these individuals are different genotypes. Selection on the parent can sometimes favour parental effects that are detrimental to offspring fitness, while selection on offspring is sometimes oblivious to parent fitness (Marshall \& Uller 2007, Uller 2008 and references therein). Crespi \& Semeniuk (2004), in considering vertebrates, argued that parent-offspring conflict over the degree of maternal investment was one of the main selective factors in evolutionary transitions among reproductive modes, independent of environmental and ecological factors.

Many of their supporting arguments might also be made for bryozoans, but as yet we have only scant data to evaluate this hypothesis. Multiple male sperm donors and the likelihood of sperm storage could represent a source of genotypic diversity, possibly advantageous in patchy or temporally variable environments (Bernasconi et al. 2004). Mothers may engage in cryptic selection through differential allocation of both resources and male genotypes, increasing their own lifetime fitness, possibly by contributing more to EEN when times are good and favoring flexibility or reduction in matrotrophic allocation in certain unfavorable times (Hunter \& Hughes 1995). Offspring, in their own 'self-interest' could be selected for deriving maximum nourishment from their mothers, consistent with evolutionary transitions toward greater EEN. Marshall (2008) demonstrated that in Bugula neritina: 'when offspring cannot exercise any control over parental investment, parents might be able to impose their own 
optimal allocation to offspring within and between broods, despite negative effects on offspring' (Uller 2008, p. 433; see also Marshall \& Uller 2007, Allen et al. 2008). When $B$. neritina colonies experience tissue loss owing to predation, larvae produced immediately after the event are smaller and less fit (Marshall \& Keough 2004). These examples reflect flexibility in resource allocation, where variable larval size can maximize both current and future reproductive returns. It has also been argued that (at least in mammals), once placentation is initially established, parent-offspring conflict will fuel further evolution and diverse morphological expression (Haig 1993). This appears to hold for bryozoans. Thus, we expect that the evolutionary transitions we infer would lead to enhanced fitness of both parents and offspring in order to be sustained under natural selection.

Our survey also revealed an unsuspected pattern among fast-growing ephemeral species with reproductive Pattern III, whereby placentation may confer an advantage in the time devoted to embryonic development. All examined cheilostome species with this ecological mode are relatively lightly calcified (suggesting fast growth), forming erect, flexible colonies that are often jointed. Insofar as incubation involves EEN, embryonic development and volumetric growth occur simultaneously. When starting reproduction, Pattern III species form the first small oocyte relatively quickly, transferring it to the brood chamber for further nutrition and development. Altogether these events can take less time than in species with Patterns II and IV, which require a longer time to form the first large (macrolecithal) oocyte. Also, the period of brooding in the latter 2 cases is of the same duration as oogenesis. Thus, the first larva, produced from a small egg with the help of the 'placenta', should be released earlierspeeding initial recruitment onto vacant substratum space. For instance, it takes 6 wk to develop a larva from the early oocyte in the perennial cheilostome Chartella papyracea (Pattern II), and just $3 \mathrm{wk}$ in the ephemeral cheilostome Bugula flabellata (Pattern III) (Dyrynda \& Ryland 1982). Pattern V (Epistomiidae) demonstrates the ultimate step in this evolutionary sequence, theoretically allowing fastest larval production (Dyrynda 1981, Dyrynda \& King 1982). Although EEN is often accompanied by prolonged embryonic development in other groups of animals, it is, in contrast, faster in at least some placental bryozoans. This difference may be maximized at times or places where food resources are abundant, according to predictions of Trexler \& DeAngelis (2003).

We reiterate our caution that these considerations are subject to validation by future phylogenetic analyses and ecological studies, but also borrow from Reznick et al. (2007, p. 2581) a thought about the value of our results. They are raw materials for the study of matrotrophy and evolution of complexity. Throughout their history, bryozoans have been an important component of benthic ecosystems. Tracing back to the early Ordovician, they survived all mass extinctions, becoming one of the dominant epibenthic groups in modern seas. Among the factors that have been linked to their episodes of radiation are growth plasticity, highly developed zooidal polymorphism, the evolution of complex body walls, and the existence of different larval types (Taylor 1988, McKinney \& Jackson 1989, Jablonski et al. 1997). We suggest that evolution of a variety of reproductive patterns and lability during development contribute to that success by offering a range of mechanisms for resource allocation (allowing different permutations and combinations of oogenesis and brooding), playing a significant role in their diversification.

Acknowledgements. We are deeply indebted to Drs N. N. Shunatova, Department of Invertebrate Zoology, St. Petersburg State University, J.-G. Harmelin, Station Marine d'Endoume, Centre d'Océanologie Marseille, B. I. Sirenko and I. S. Smirnov, Laboratory of Marine Researches, Zoological Institute of Russian Academy of Sciences, St. Petersburg, P. E. Bock, School of Ecology and Environment, Deakin University, Burwood, and M. Carter, NIWA Invertebrate Collection, National Institute of Water and Atmospheric Research, Wellington, for material. The research was sponsored by the Alexander von Humboldt Foundation (Germany), the Lise Meitner Foundation and FWF Grant P19337-B17 (Austria), and RFBR grants 07-04-00928a and 07-04-10046k (Russia). Anonymous reviewers provided useful comments.

\section{LITERATURE CITED}

Adiyodi KG, Adiyodi RG (eds) (1989) Reproductive biology of invertebrates, Vol IV, Part A. Fertilization, development, and parental care. IBH Publishing, New Delhi

Adiyodi KG, Adiyodi RG (eds) (1990) Reproductive biology of invertebrates, Vol IV, Part B. Fertilization, development, and parental care. IBH Publishing, New Delhi

Allen RM, Buckley YM, Marshall DJ (2008) Offspring size plasticity in response to intraspecific competition: an adaptive maternal effect across life-history stages. Am Nat 171:225-237

Arthur W (2004) The effect of development on the direction of evolution: toward a twenty-first century consensus. Evol Dev 6:282-288

Banta WC (1968) Mimosella cookae, new species (Bryozoa, Ctenostomata) with a review of the family Mimosellidae. Bull S Calif Acad Sci 67:245-254

Bernasconi G, Ashman TL, Birkhead TR, Bishop JDD and others (2004) Evolutionary ecology of the prezygotic stage. Science 303:971-975

> Bishop JDD, Pemberton AJ (2006) The third way: spermcast mating in sessile marine invertebrates. Integr Comp Biol 46:398-406

Bishop JDD, Manriquez PH, Hughes RN (2000) Water-borne sperm trigger vitellogenic egg growth in two sessile marine invertebrates. Proc R Soc Lond B 267:1165-1169 
Blackburn DG (1992) Convergent evolution of viviparity, matrotrophy, and specializations for fetal nutrition in reptiles and other vertebrates. Am Zool 32:313-321

Bone Q (ed) (1998) The biology of pelagic tunicates. Oxford University Press, Oxford

Borg F (1926) Studies on Recent cyclostomatous Bryozoa. Zool Bidr Upps 10:181-507

Braem F (1890) Untersuchungen über die Bryozoen des süssen Wassers. Bibl Zool 2:1-134

- Braem F (1939) Victorella sibogae Harmer. Z Morphol Oekol Tiere 36:267-278

Brien P (1953) Etude sur les Phylactolemates. Ann Soc R Zool Belg 84:301-440

Byrne M (1991) Developmental diversity in the starfish genus Patiriella (Asteroidea: Asterinidae). In: Yanagisawa T, Yasumasu I, Oguro C, Suzuki N, Motokawa T (eds) Biology of Echinodermata. AA Balkema, Rotterdam, p 499-508

Byrne M (1996) Viviparity and intragonadal cannibalism in the diminutive asterinid sea stars Patiriella vivipara and $P$. parvivipara. Mar Biol 125:551-567

Byrne M, Cerra A (1996) Evolution of intragonadal development in the diminutive asterinid sea stars Patiriella vivipara and $P$. parvivipara with an overview of development in the Asterinidae. Biol Bull 191:17-26

Charmantier G, Charmantier-Daures M (1994) Ontogeny of osmoregulation and salinity tolerance in the isopod crustacean Sphaeroma serratum. Mar Ecol Prog Ser 114: 93-102

Cook PL (1985) Bryozoa from Ghana. Ann Mus R Afr Cent Sci Zool 238:1-315

- Crespi B, Semeniuk C (2004) Parent-offspring conflict in the evolution of vertebrate reproductive mode. Am Nat 163: 635-653

Dyrynda PEJ (1981) A preliminary study of patterns of polypide generation-degeneration in marine cheilostome Bryozoa. In: Larwood GP, Nielsen C (eds) Recent and fossil Bryozoa. Olsen \& Olsen, Fredensborg, p 73-81

Dyrynda PEJ, King PE (1982) Sexual reproduction in Epistomia bursaria (Bryozoa: Cheilostomata), an endozooidal brooder without polypide recycling. J Zool 198:337-352

Dyrynda PEJ, King PE (1983) Gametogenesis in placental and non-placental ovicellate cheilostome Bryozoa. J Zool 200: 471-492

Dyrynda PEJ, Ryland JS (1982) Reproductive strategies and life histories in the cheilostome marine bryozoans Chartella papyracea and Bugula flabellata. Mar Biol 71: 241-256

Elkin C, Marshall DJ (2007) Desperate larvae: influence of deferred costs and habitat requirements on habitat selection. Mar Ecol Prog Ser 335:143-153

Giese AC, Pearse JS (eds) (1974) Reproduction of marine invertebrates, Vol 1. Acoelomate and pseudocoelomate metazoans. Academic Press, New York

Giese AC, Pearse JS (eds) (1975a) Reproduction of marine invertebrates, Vol 2. Entoprocts and lesser coelomates. Academic Press, New York

Giese AC, Pearse JS (eds) (1975b) Reproduction of marine invertebrates, Vol 3. Annelids and echiurans. Academic Press, New York

Giese AC, Pearse JS (eds) (1977) Reproduction of marine invertebrates, Vol IV. Molluscs: gastropods and cephalopods. Academic Press, New York

Giese AC, Pearse JS, Pearse VB (eds) (1979) Reproduction of marine invertebrates, Vol V. Molluscs (pelecypods and lesser classes). Academic Press, New York

Giese AC, Pearse JS, Pearse VB (eds) (1987) Reproduction of marine invertebrates, Vol IX. General aspects: seeking unity in diversity. Boxwood Press, Pacific Grove, CA
Giese AC, Pearse JS, Pearse VB (eds) (1991) Reproduction of marine invertebrates, Vol VI. Echinoderms and lophophorates. Boxwood Press, Pacific Grove, CA

Glaubrecht M, Feher Z, von Rintelen T (2006) Brooding in Corbicula madagascariensis (Bivalvia, Corbiculidae) and the repeated evolution of viviparity in corbiculids. Zool Scr 35:641-654

Gordon DP (2000) Towards a phylogeny of cheilostomes morphological models of frontal wall/shield evolution. In: Herrera Cubilla A, Jackson JBC (eds) Proceedings of the 11th International Bryozoological Association conference. Smithsonian Tropical Research Institute, Balboa, p 17-37

> Haig D (1993) Genetic conflicts in human-pregnancy. Q Rev Biol 68:495-532

Harmer SF (1893) On the occurrence of embryonic fission in cyclostomatous Polyzoa. Q J Microsc Sci 34:199-241

Harmer SF (1896) On the development of Lichenopora verrucaria Fabr. Q J Microsc Sci 39:71-144

Harmer SF (1898) On the development of Tubulipora, and on some British and northern species of this genus. Q J Microsc Sci 41:73-157

Harmer SF (1902) On the morphology of the Cheilostomata. Q J Microsc Sci 46:263-350

Harmer SF (1926) The Polyzoa of the Siboga Expedition. II. Cheilostomata. Siboga Exped 28b:181-501

Hughes DJ (1987) Gametogenesis and embryonic brooding in the cheilostome bryozoan Celleporella hyalina. J Zool (Lond) 212:691-711

> Hughes RN, Manriquez PH, Bishop JDD (2002) Female investment is retarded pending reception of allosperm in a hermaphroditic colonial invertebrate. Proc Natl Acad Sci USA 99:14884-14886

Hunter E, Hughes RN (1995) Environmental and genetic components of variation in sexual allocation by an epialgal bryozoan. Mar Ecol Prog Ser 120:193-201

> Jablonski D, Lidgard S, Tayor PD (1997) Comparative ecology of bryozoan radiations: origin of novelties in cyclostomes and cheilostomes. Palaios 12:505-523

Jackson JBC (1986) Modes of dispersal of clonal benthic invertebrates - consequences for species distributions and genetic-structure of local-populations. Bull Mar Sci 39:588-606

Joliet L (1877) Contributions à l'histoire naturelle des Bryozoaires des côtes de France. Arch Zool Exp Gen 6: 193-304

Korneva ZhV (2005) Placental type interactions and evolutionary trends of development of uterus in cestodes. J Evol Biochem Physiol 4:442-449

> Koya Y, Munoz M (2007) Comparative study on ovarian structures in scorpaenids: possible evolutional process of reproductive mode. Ichthyol Res 54:221-230

Lidgard S, McKinney FK, Taylor PD (1993) Competition, clade replacement, and a history of cyclostome and cheilostome bryozoan diversity. Paleobiology 19:352-371

Lombardi J (1998) Comparative vertebrate reproduction. Kluwer Academic Publishers Group, Boston, MA

Marcus E (1938) Bryozoarios marinhos brasileiros. II. Bol Fac Filos Cienc Let Univ Sao Paulo Ser Zool 2:1-196

Marcus E (1941) Sobre o desenvolvimento do bryozoario Synnotum aegyptiacum. Arq Cir Clin Exp 5:227-234

- Marshall DJ (2008) Transgenerational plasticity in the sea: context-dependent maternal effects across the life history. Ecology 89:418-427

Marshall DJ, Keough MJ (2003) Variation in the dispersal potential of non-feeding invertebrate larvae: the desperate larva hypothesis and larval size. Mar Ecol Prog Ser 255:145-153

Marshall DJ, Keough MJ (2004) Variable effects of larval size 
on post-metamorphic performance in the field. Mar Ecol Prog Ser 279:73-80

Marshall DJ, Keough MJ (2006) Complex life cycles and offspring provisioning in marine invertebrates. Integr Comp Biol 46:643-651

Marshall DJ, Keough MJ (2008a) The evolutionary ecology of offspring size in marine invertebrates. Adv Mar Biol 53: $1-60$

Marshall DJ, Keough MJ (2008b) The relationship between offspring size and performance in the sea. Am Nat 171: 214-224

Marshall DJ, Uller T (2007) When is a maternal effect adaptive? Oikos 116:1957-1963

> Marshall DJ, Bolton TF, Keough MJ (2003) Offspring size affects the post-metamorphic performance of a colonial marine invertebrate. Ecology 84:3131-3137

Marshall DJ, Allen RM, Crean AJ (2008a) The ecological and evolutionary importance of maternal effects in the sea. Oceanogr Mar Biol Annu Rev 46:203-250

Marshall DJ, Bonduriansky R, Bussiere LF (2008b) Offspring size variation within broods as a bet-hedging strategy in unpredictable environments. Ecology 89:2506-2517

McKinney FK, Jackson JDC (1989) Bryozoan evolution. Unwin Hyman, Boston, MA

Mess A, Carter AM (2007) Evolution of the placenta during the early radiation of placental mammals. Comp Biochem Phys Part A 148:769-779

Mousseau TA, Fox C (eds) (1998) Maternal effects as adaptations. Oxford University Press, Oxford

Ostrovsky AN (1998) Comparative studies of ovicell anatomy and reproductive patterns in Cribrilina annulata and Celleporella hyalina (Bryozoa: Cheilostomatida). Acta Zool 79:287-318

Ostrovsky AN (2008) The parental care in cheilostome bryozoans: a historical review. In: Wyse Jackson PN, Spencer Jones ME (eds) Annals of bryozoology 2: aspects of the history of research on bryozoans. International Bryozoology Association, Dublin, p 211-245

Ostrovsky AN, Taylor PD (2005) Brood chambers constructed from spines in fossil and Recent cheilostome bryozoans. Zool J Linn Soc 144:317-361

Ostrovsky AN, Vávra N, Porter JS (2008) Sexual reproduction in gymnolaemate Bryozoa: history and perspectives of the research. In: Wyse Jackson PN, Spencer Jones ME (eds) Annals of bryozoology 2: aspects of the history of research on bryozoans. International Bryozoology Association, Dublin, p 117-210

Pace RM (1906) On the early stages in the development of Flustrellidra hispida (Fabricius), and on the existence of a 'yolk nucleus' in the egg of this form. Q J Microsc Sci 50: $435-478$

Prouho H (1892) Contribution a l'histoire des bryozoaires. Arch Zool Exp Gen 10:557-656

Reed CG (1991) Bryozoa. In: Giese AC, Pearse JS, Pearse VB (eds) Reproduction of marine invertebrates, Vol VI. Echinoderms and lophophorates. Boxwood Press, Pacific Grove, CA, p 85-245

Reznick D, Meredith R, Collette BB (2007) Independent evolution of complex life history adaptations in two families of fishes, live-bearing halfbeaks (Zenarchopteridae, Beloniformes) and Poeciliidae (Cyprinodontiformes). Evolution 61:2570-2583

Richardson KC, Jarrett L, Finke EH (1960) Embedding in epoxy resins for ultrathin sectioning in electron microscopy. Stain Technol 35:313-323

Santagata S, Banta WC (1996) Origin of brooding and ovicells in cheilostome bryozoans: interpretive morphology of
Scrupocellaria ferox. Invertebr Biol 115:170-180

Schwartz ML, Dimock RV Jr (2001) Ultrastructural evidence for nutritional exchange between brooding unionid mussels and their glochidia larvae. Invertebr Biol 120:227-236

Silén L (1942) Origin and development of the cheilo-ctenostomatous stem of Bryozoa. Zool Bidr Upps 22:1-59

Silén L (1944) The anatomy of Labiostomella gisleni Silén (Bryozoa Protocheilostomata). K Sven Vetenskapsakad Handl 3 21:1-111

Strathmann RR (1985) Feeding and nonfeeding larval development and life-history evolution in marine invertebrates. Annu Rev Ecol Syst 16:339-361

Strathmann RR (2007) Three functionally distinct kinds of pelagic development. Bull Mar Sci 81:167-179

Ström R (1977) Brooding patterns of bryozoans. In: Woollacott RM, Zimmer RL (eds) Biology of bryozoans. Academic Press, New York, p 23-56

Taylor PD (1988) Major radiation of cheilostome bryozoans: Triggered by the evolution of a new larval type? Hist Biol 1:45-64

Taylor PD, Michalik J (1991) Cyclostome bryozoans from the Late Triassic (Rhaetian) of the West Carpathians, Czechoslovakia. Neues Jahrb Geol Palaeontol Abh 182:285-302

Todd JA (2000) The central role of ctenostomes in bryozoan phylogeny. In: Herrera Cubilla A, Jackson JBC (eds) Proceedings of the 11th International Bryozoology Association conference. Smithsonian Tropical Research Institute, Balboa, p 104-135

> Trexler JC, DeAngelis DL (2003) Resource allocation in offspring provisioning: an evaluation of the conditions favoring the evolution of matrotrophy. Am Nat 162: $574-585$

Uller T (2008) Developmental plasticity and the evolution of parental effects. Trends Ecol Evol 23:432-438

von Rintelen T, Glaubrecht M (2005) Anatomy of an adaptive radiation: a unique reproductive strategy in the endemic freshwater gastropod Tylomelania (Cerithioidea: Pachychilidae) on Sulawesi, Indonesia and its biogeographical implications. Biol J Linn Soc 85:513-542

Waters A (1912) A structure in Adeonella (Laminopora) contorta (Michelin) and some other Bryozoa, together with remarks on the Adeonidae. Ann Mag Nat Hist 8 (Ser 9): 489-500

Waters A (1913) The marine fauna of British East Africa and Zanzibar, from collections made by Cyril Crossland, MA, BSc, FZS, in the years 1901-1902. Bryozoa-Cheilostomata. Proc Zool Soc Lond, p 458-537

Waters A (1914) The marine fauna of British East Africa and Zanzibar, from collections made by Cyril Crossland, MA, BSc, FZS, in the years 1901-1902. Bryozoa-Cyclostomata, Ctenostomata and Endoprocta. Proc Zool Soc Lond, p 831-858

Weygoldt P (1969) Biology of pseudoscorpions. Harvard University Press, Cambridge, MA

Woollacott RM, Zimmer RL (1972) Origin and structure of the brood chamber in Bugula neritina (Bryozoa). Mar Biol 16:165-170

Woollacott RM, Zimmer RL (1975) A simplified placenta-like system for the transport of extraembryonic nutrients during embryogenesis of Bugula neritina (Bryozoa). J Morphol 147:355-378

Wourms JP, Lombardi J (1992) Reflections on the evolution of piscine viviparity. Am Zool 32:276-293

Wourms JP, Grove PD, Lombardi J (1988) The maternalembryonic relationship in viviparous fishes, Vol 11B. In: Hoar DC, Randall DJ (eds) Fish physiology. Academic Press, San Diego, CA, p 1-134 